\title{
A ANÁLISE DA ABRASÃO DENTÁRIA COMO INDICADOR DA PALEODIETA E PALEONUTRIÇÃO NO SÍTIO JUSTINO E SÃO JOSÉ II, SERGIPE- BRASIL
}

Iris Machado Marques de Souza

Olivia Alexandre de Carvalho **

*Arqueologa_formada pela
Universidade Federal de Sergipe
irismachado87@gmail.com

**Departamento de Arqueologia Universidade Federal de Sergipe - UFS ocarvalho99@hotmail.com
RESUMO: Este projeto visa o estudo da paleodieta e da paleonutrição, com objetivo de expandir o conhecimento sobre as interações do homem do passado com o meio ambiente e a exploração de seus recursos de origem animal e vegetal, expandindo assim o conhecimento do indivíduo como agente transformador e tomador de decisões. Para tal foi realizada a análise de laboratório dos dentes, utilizando a metodologia descrita por BUIKSTRA, J. E.; UBELAKER, D. H. (1994). Empregando as análises patológicas que servem como indicadores não específicos dos tipos de dieta e da qualidade nutricional, para as análises dos enterramentos dos sítios Justino e São José II, realizadas nos laboratórios da UFS Campus Laranjeiras. Identificando e registrando as paleopatologias orais que poderiam identificar o tipo de dieta e a qualidade de vida dessa população. Sendo identificado a intensidade da abrasão dentária, dentro desse estudo sugere-se que esta modificação não se encontra associada a nenhuma infecção visível, podendo estar relacionada a uma dieta baseada em alimentos duros e grosseiros. Sendo esse o tipo de alimentação predominante em grupos caçadores-coletores.

Palavras-chaves: Paleodieta, Paleopatologias, Nutrição, Estresse Nutricional.

ABSTRACT: This project aims to study the Paleodiet and Paleonutrition, in order to expand the knowledge about the interactions of man's past with the environment and the exploitation of its resources of animal and vegetable origin, thus expanding the understanding of the individual as a trasforming agent and decision maker. For such laboratory teeth and bones were analyzed, using the methodology described by BUIKSTRA, J. E. B.; Ubelaker, D. H. (1994). In the pathological analyses that serve as indicators of non-specific type of diet and nutritional quality of the analyzed burials of the Justino, and São José II sites, placed in the laboratories of the UFS Campus Laranjeiras. Identifying and recording the oral paleopathologies that could identify the type of paleodiet and quality of life of this population. As the intensity of tooth abrasion is identified, within this study, it suggests that this modification is not associated with visible infections, may be related to a diet based on hard and coarse food. Once this is the food type predominant in Hunter-gathering groups. Keywords: Paelodiet, Paleopathology, Nutrition, Nutritional Stress. 


\section{Introdução}

Este trabalho tem por objetivo apresentar como os estudos da paleodieta em populações passadas através da Bioarqueologia, vêm acrescentar a compreensão sobre as estruturas e interações do homem do passado com o meio. Sendo o ser humano pensante e ativo, encontra diversifica e cria as mais variadas soluções, para situações semelhantes ou antagônicas, ou seja, não necessariamente o encontro dos mesmos fatores irá gerar o mesmo coeficiente, pois o ser humano, será motivado não somente por questões lógicas, partindo inclusive da premissa que sua lógica também contém traços de sua criação, de sua cultura, além de suas inclinações pessoais como indivíduo autônomo.

O estudo Bioarqueológico traz consigo os elementos necessários para a análise de vestígios orgânicos. Dentro da Bioarqueologia têm-se os elementos necessários para buscar compreender a interação Homem-Ambiente. Tais informações empregadas para elucidar essas interações, podem ser obtidas ao analisar os vestígios ósseos e dentários, que preservam dados sobre as interações e o modo de vida das populações passadas. Segundo Price, et al, (1985), o estudo do comportamento alimentar é reforçado pela integração de patologias nutricionais, morfologias e análises químicas, anunciando um novo capítulo na análise de dietas alimentares. O estudo em conjunto com disciplinas de outras áreas como a paleoecologia humana contribuem para analisar as relações do homem no ambiente biótico e abiótico. "Podendo a Bioarqueologia lançar hipóteses em aspectos bio-culturais, ultrapassando a métrica descritiva da osteologia humana. Adotando o estudo de micro resíduos e investigações bioquímicas de dietas a partir dos tecidos duros" (Mendonça de Souza, 1999: p. 89)

Os estudos acerca da Paleodieta visam esclarecer mais do que a rotina alimentar de uma população passada, mas se relaciona intrinsecamente à Paleonutrição. As análises nutricionais vêm da busca por recursos energéticos, sendo os recursos heterotróficos o foco das relações humanas para a sobrevivência e continuidade da espécie. Investigar a Paleodieta, se torna a investigar as formas de interações e resoluções do homem do passado em questões ligadas à sua preferência alimentar e sobrevivência, dependendo das intempéries climáticas de outrora. "A Paleodieta inclui direcionamento espacial, sobre a variação da dieta, incluindo a adoção da agricultura, status, idade, sexo. Movimentando questões como residência e mobilidade" (Katzenberg; Harrison, 1997: 266). Têm-se três linhas principais de pesquisa que permitem 
investigar a Paleoalimentação, sendo elas: os recursos de fauna e flora; vestígios de cerâmica e ferramentas; e indicadores de saúde (Trancho; Robledo, 1999) que tem o acréscimo de três linhas de investigação direta sobre a paleoalimentação: a análise dos elementos-traço; análise isotópica e a investigação de paleopatologias (Trancho e Robledo, 1999).

Para as investigações se empregam amostras humanas e não humanas, obtendo um melhor esclarecimento do meio ambiente e das relações energéticas efetuadas pela cadeia trófica desse sistema, sendo adotadas, além de técnicas para análise físico-química de elementos-traço, isótopos estáveis, extração de DNA e extração de lipídeos (Katzenberg, Harrison, 1997). Os tecidos duros (ossos e dentes) tiveram sua análise intensificada após os testes nucleares no fim da Segunda Guerra Mundial, tendo gerado a curiosidade sobre como a atomicidade afeta a matéria e como funcionam suas estruturas constituintes, podendo esse processo fornecer dados sobre o ambiente e status de vida, saúde etc.

De acordo com White; Folkens (2000), as patologias observáveis são resultantes de alterações e interações de fatores como alterações no abastecimento sanguíneo, inflamação de tecidos moles, desequilíbrios hormonais, nutricionais e metabólicos. As patologias ósseas observáveis se tornam indicadores não específicos de paleonutrição, pois através do estudo da etiologia das mesmas é possível encontrar situações de desequilíbrio nutricional ou metabólico gerado ou não por uma carência alimentar. Usualmente a forma mais recorrente de anemia provém de carência nutricional, sendo o principal fator a deficiência de Ferro na alimentação, que pode ser encontrado em abundância nas carnes vermelhas, e em menores quantidades em legumes e pescados (Roberts; Manchester, 1995: 558).

O ferro oriundo de plantas é de difícil absorção e os componentes chamados fitatos, existentes nos cereais (milho), retardam a absorção de ferro (assim como a vitamina C auxilia na absorção). Porém, diversas infecções podem desencadear o processo anêmico. "As transições de caçadorcoletor para economias baseadas em agricultura revelam que os cereais para uma adequada variação alimentar levaram a uma deficiência de ferro no passado" (Roberts; Manchester, 1995:541). As patologias orais exemplificam demasiadamente os padrões alimentares em vida dos indivíduos. A dieta está relacionada ao processo saúde-doença em muitos dos seus aspectos e, em particular, a condições fisiopatológicas que afetam os dentes e a boca.

A inserção de tubérculos e cereais na alimentação de grupos de pessoas no passado pode ter exercido um efeito patológico na saúde oral dessas populações, pois são alimentos encontrados na natureza com alto teor de amido. Em face da sua rápida digestão, o amido inicia a quebra de 
suas moléculas através da enzima ptialina existente na boca, ocasionando uma queda do $\mathrm{pH}$ bucal. Neste contexto, o decréscimo ocasionado pelo açúcar prolonga-se por mais tempo, “(...) se o alimento contiver amido e açúcar terá um alto índice cariogênico" (Hillson, 1996: 278).

Nesse cenário podem surgir patologias como a cárie dentária, caracterizada pela destruição dos tecidos dentários, devido à ação de bactérias, intermediadas por ácidos, geralmente o ácido láctico, resultado da fermentação de carboidratos e açúcares, ocasionando a baixa do pH e a desmineralização dos dentes. Ela sendo compreendida como uma infecção orquestrada pelo tipo de dieta e pelas condições ecológicas do ambiente oral. De acordo com Buikstra ; Ubelaker (1994), o desgaste dental no estudo de reconstruções alimentares pode explicar sobre padrões de preparação de alimentos, sendo dessa forma exemplificado que as dietas mais grosseiras (mais usuais em grupos caçadores-coletores) acompanham um desgaste mais intenso. Diminuindo as zonas desgastadas é possível estimar uma mudança dietética, tanto na qualidade quanto na tecnologia usada no preparo.

Sendo analisados vários tipos de patologias orais relacionadas aos hábitos alimentares, foi realizada a identificação, medição e registro de abrasões, cáries e outros elementos por ventura encontrados, adotando a metodologia descrita por Buikstra; Ubelaker (1994). Foram realizadas análises nos vestígios de crânios, mandíbulas, maxilares e dentes, de amostras dos sítios do Justino e São José II.

\section{Revisão de Literatura}

\section{Bioarquelogia}

Nos últimos anos a Bioarqueologia vem conquistando espaço como área de estudo e pesquisa arqueológica. Dentro da Bioarqueologia encontram-se três grandes ramos e suas subdivisões, sendo eles: Antropologia Biológica, Zooarqueologia e Arqueobotânica. Aplicadas à Arqueologia vêm gerando grandes contribuições e avanços nas pesquisas, trazendo resultados conclusivos ao que antes permeava alhures hipotéticos, elucidando questões antes refutáveis, de uma análise unicamente macroscópica do sítio. O emprego do estudo pluri-interdisciplinar com outras áreas como a paleoecologia humana, vem auxiliando a Bioarqueologia a entender as relações estabelecidas pelo homem do passado com o ambiente biótico e abiótico. "Podendo a Bioarqueologia lançar hipóteses em aspectos bio-culturais, ultrapassando a métrica descritiva da osteologia humana. Adotando o estudo de micro resíduos e investigações bioquímicas de dietas a partir dos tecidos duros" (Mendonça de Souza, 1999: p. 89). 
Sendo assim, a Bioarqueologia vem dar a sua contribuição à Arqueologia no auxílio de reconstituições cotidianas. Sendo o ser humano pensante e ativo, encontra, diversifica e cria as mais variadas soluções, para situações semelhantes ou antagônicas.

"As reconstruções do modo de vida das populações do passado envolvem uma noção central para a antropologia biológica: O conceito de estresse. Esse conceito tem um caráter integrador já que perpassam campos como a antropologia, a fisiologia, a patologia e a osteologia" (Glória, 2006: 5).

Neste contexto, a contribuição oriunda da Bioarqueologia em suas multifacetárias análises vem permitir compreender sobre o tipo de alimentação, suas preferências alimentares, inclusive em alguns casos de acordo com a organização dos vestígios no sítio, inferindo sobre estruturas sócio econômicas. "Três linhas de pesquisa permitem estimar indiretamente a dieta de populações antigas, são elas: os recursos de flora e fauna disponíveis, a evidência arqueológica baseada nas cerâmicas e ferramentas utilizadas e o estudo de indicadores de saúde" (Trancho e Robledo, 1999: 1).

Dentro da Antropologia Biológica há vários estudos que auxiliam na compreensão das estruturas culturais/sociais, essas informações são extraídas dos vestígios de tecidos (cabelos, pele, ossos, dentes etc.). Normalmente se encontra em maior proporção de vestígios de tecidos duros, como ossos e dentes. A compreensão sobre o funcionamento da cadeia trófica e de como os elementos são metabolizados e armazenados em nosso corpo é imprescindível para o estudo da dieta e nutrição de populações passadas. Analisando a Figura 1 observa-se tais relações:

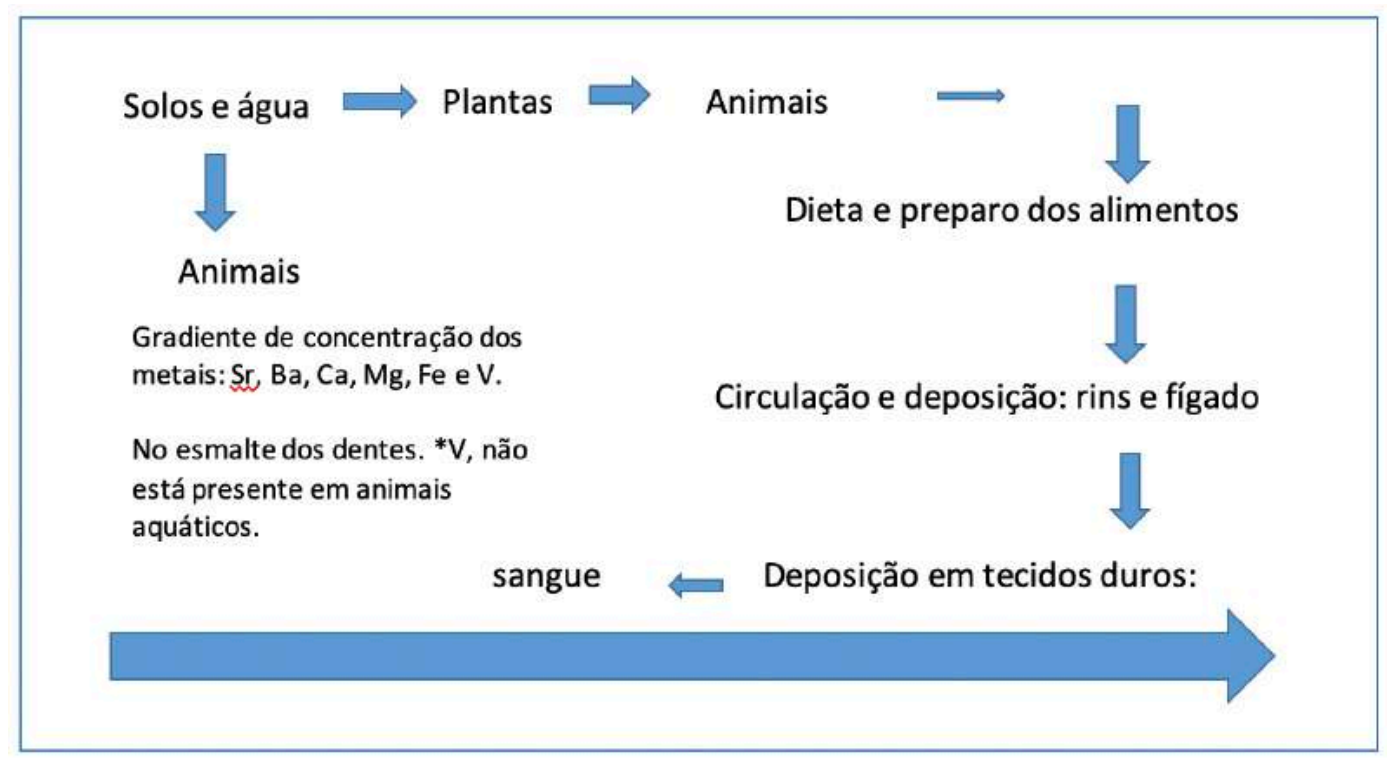

Figura 1: Dinâmica de mobilização dos elementos - traço na cadeia trófica. 
O osso humano é composto principalmente por dois componentes, a fração inorgânica mineral, que representa cerca de $30 \%$, sendo que deles aproximadamente $90 \%$ será composta por colágeno. O componente mineral dos ossos humanos, incluindo os dentes, é em sua primazia cristais de fosfato de cálcio ( $\mathrm{Ca} 10[\mathrm{PO} 4] 6[\mathrm{HO} 2$ ), sendo esse composto análogo a molécula geológica hidroxiapatita. O crescimento ósseo e a sua manutenção são sensíveis a fatores como a nutrição, o estresse bioquímico e a idade.

Paleodieta

Investigar a paleodieta se traduz no estudo da forma como o homem do passado interagia com o ambiente, onde buscava solucionar questões acerca de sua preferência alimentar e sobrevivência, dependendo das intempéries climáticas de outrora. O estudo da paleodieta inclui a interação dos grupos humanos do passado com os processos climáticos sazonais e os processos de adoção da agricultura. Os seus indicadores revelam, de acordo com o objetivo da pesquisa, as diferentes funções dentro dos grupos, por status, idade, gênero, e sobre a fixação e mobilidade dos mesmos. Os estudos de paleodieta visam esclarecer mais do que a rotina alimentar de uma população do passado, mas encontram-se intrinsecamente relacionados a paleonutrição. Isto se dá, pois as análises nutricionais vêm da busca por recursos energéticos, sendo os heterotróficos o foco das relações humanas para a sua sobrevivência e continuidade da espécie, podendo ser analisada por indicadores conclusivos e não conclusivos. As análises dos indicadores não conclusivos feitos através da pesquisa dos ossos e dentes visou encontrar sinais de paleopatologias, como hiperostose porótica, osteoporose etc, por meio das etiologias observadas.

Para compor o estudo da paleodieta se empregam amostras humanas e não humanas, assim tem-se uma melhor noção do paleoambiente e das relações energéticas das antigas cadeias tróficas. "O estudo da paleodieta inclui agora a extração de DNA, a análise de lipídeos e a adoção de elementos traços e isótopos estáveis" (Katzenberg; Harrison, 1997: 265). A análise dos componentes ósseos foi intensificada depois dos testes nucleares no final da Segunda Guerra Mundial. Esse evento gerou a curiosidade sobre os efeitos na matéria ocasionados pela atomicidade dos elementos. Sendo assim, as estruturas formadoras de tais elementos informam sobre o desenvolvimento do processo, fornecendo informações acerca do ambiente, qualidade de vida, status, estresse, doenças etc. "Para entender o contexto da paleodieta, paleonutrição e qualidade de vida das populações do passado, temos que abrir três linhas de investigação, 
sendo elas: a análise dos elementos, análise isotópica e paleopatologias" (Trancho e Robledo, 1999: 1).

\section{Elementos-traço}

Os micros minerais ou oligoelementos também conhecidos como elementos-traço, estão presentes em todos os organismos vivos, sendo eles responsáveis pelo equilíbrio da homeostase do corpo. A maioria dos tecidos vivos é composta por vários elementos, tendo alguns, mais ocorrência que os demais. Os mais comuns são Carbono (C), Nitrogênio (N), Oxigênio (O) e Enxofre (S). Já os elementos Sódio ( $\mathrm{Na})$, Magnésio $(\mathrm{Mg})$, Fósforo $(\mathrm{P})$, Cloro $(\mathrm{Cl})$, Potássio $(\mathrm{K})$, Cálcio (Ca), Zinco (Zn), são essenciais para a estrutura tecidual e fluida do corpo.

O problema encontrado na análise dos elementos-traço é a diagênese que acaba por interferir nos resultados das amostras nos post-mortem. "Elementos como o manganês, alumínio e potássio foram significativamente alterados nos processos pós- deposicionais" (Laubert et. al., 1983 apud Price, et al, 1985: 427). Elementos como o Zinco (Zn) , o Sódio (Na) e o Estrôncio (Sr) podem não apresentar grandes alterações depois do enterramento, sendo o estudo de grande valia para o entendimento do passado.

A análise do Estrôncio em restos humanos pré-históricos é iniciada em 1973, por A. B. Brown. 0 estudo das relações Estrôncio/Cálcio nos restos ósseos e dentários pode inferir sobre o tipo de alimentação predominante de uma determinada população, o uso de recursos terrestres de origem vegetal, ou seja, analisar os índices de $\mathrm{Sr} / \mathrm{Ca}$, pode fornecer noções sobre o grau de carnivorismo de uma população do passado.

"Devemos ser conscientes de que o resto ósseo pode estar submetido ao intercâmbio iônico, a maior profundidade da capa superficial e a abrasão mecânica, [...] poderá não ser sempre suficiente para resolver o problema analítico (Trancho e Robledo, 1999: 5)".

Os elementos Cálcio e Fósforo são encontrados em maiores concentrações no tecido ósseo, mas acaba não apresentando uma válida contribuição para o estudo da paleodieta, entretanto as análises de suas relações como as de Sr/Ca, são válidas. O magnésio encontra-se presente em cereais, vegetais verdes e legumes, apresenta valores altos, tanto nas amostras humanas como na fauna. A seguir pode-se observar como tais elementos representam em um nível trófico o teor de carnivorismo/herbivorismo de uma determinada população (Tabela 1). 
Tabela 1: Elementos e níveis tróficos: adaptação de Trancho e Robledo, (1999).

\begin{tabular}{|c|c|c|}
\hline & Fonte alimentícia & Absorção \\
\hline $\mathrm{Ba}$ & $\begin{array}{l}\text { Fibra vegetal, tubérculos, legumes, Herbívoro-carnívoro } \\
\text { frutos secos, carne. }\end{array}$ & Algo digenético \\
\hline $\mathrm{Cu}$ & $\begin{array}{l}\text { Crustáceos, moluscos, vísceras, Carnívoro-herbívoro } \\
\text { carnes, frutos secos, mel. }\end{array}$ & Similar ao bário \\
\hline $\mathrm{Mg}$ & $\begin{array}{l}\text { Vegetais verdes, cereais, legumes, Herbívoro-carnívoro } \\
\text { frutos secos, carne. }\end{array}$ & $\begin{array}{l}\text { Em altos níveis associa-se a } \\
\text { dietas ricas em cereais }\end{array}$ \\
\hline $\mathrm{Sr}$ & $\begin{array}{l}\text { Ecossistemas marinhos, } \\
\text { vegetal em geral. }\end{array}$ & Muito utilizado na paleodieta \\
\hline V & $\begin{array}{l}\text { Tubérculos, legumes, frutos secos, Herbívoro-carnívoro } \\
\text { leite. }\end{array}$ & $\begin{array}{l}\text { Pouco conhecido em nível de } \\
\text { paleodieta }\end{array}$ \\
\hline $\mathrm{Zn}$ & $\begin{array}{l}\text { Crustáceos, moluscos, } \\
\text { cereais. }\end{array}$ & $\begin{array}{l}\text { Diagenéticamente estável, muito } \\
\text { usado na paleodieta. }\end{array}$ \\
\hline
\end{tabular}

Segundo Trancho e Robledo (1999), o Fe, seria um indicador de diagênese do solo ao osso. O elemento Vanádio (V) é essencial para o metabolismo da gordura, sendo que a dieta rica em leite, cereais e tubérculos, trará elevadas concentrações desse elemento. Por este motivo as crianças tendem a ser portadoras de um nível superior de Vanádio durante o aleitamento materno. As taxas de Bário (Ba), próximos aos altos níveis de Magnésio $(\mathrm{Mg})$, sugere uma dieta pobre em frutos secos e rica em cereais. Sendo essa relação um dos indicadores sobre a transição entre grupos caçadores-coletores e agricultores. Outro fator relevante ao estudo de necrópoles diz respeito à proporção de patologias orais, como cáries, abrasão dentária e infecções, pois pode estar relacionado ao referido período de transição econômica ou algum período de seca e escassez alimentar.

Durante os variados níveis tróficos as proporções de $\mathrm{Sr} / \mathrm{Ca}$, servem para diferenciar os herbívoros dos carnívoros e onívoros. "O zinco (Zn) se incrementa ao longo da cadeia trófica, já que são retidos nos tecidos musculares que serviram de alimentos a carnívoros e onívoros. Desta maneira o zinco junto com o bário $(\mathrm{Ba})$ mantém níveis que permitem diferenciar os herbívoros dos carnívoros (Trancho e Robledo, 1999: 10)". 


\section{Paleopatologias}

As paleopatologias surgem como uma ferramenta no estudo de populações do passado, auxiliando na compreensão da adaptação ao meio e do modo de vida dessas populações. De acordo com White (2000), as patologias observáveis são resultado de alterações e interações de fatores como alterações no abastecimento sanguíneo, inflamação de tecidos moles, desequilíbrios hormonais, nutricionais e metabólicos. As patologias ósseas observáveis se tornam indicadores não específicos de paleonutrição, pois através do estudo da etiologia das mesmas é possível encontrar situações de desequilíbrio nutricional ou metabólico, gerado ou não por uma carência alimentar. Dentro desse objeto de estudo tem-se a análise de alguns marcadores indiretos, que auxiliam no estudo e compreensão dessas populações como as paleopatologias ósseas (anemia, hiperostose porótica, linhas de Harris, carência de vitamina C e D etc.). Assim como algumas patologias orais, como a hipoplasia linear do esmalte dentário, as cáries, a abrasão dentária etc.

Para a identificação desses marcadores paleopatológicos nos esqueletos é necessária uma análise sistemática, uma vez que a identificação das patologias dentro da arqueologia possui uma abordagem diferente da clínica. "Os dados produzidos pela análise química do material ósseo e dentário, tem um potencial indicador sobre o tipo de dieta de um indivíduo, em comparação as gravações paleopatológicas que são somente uma alusão sobre o status alimentar e seus efeitos na saúde" (Roberts; Manchester, 1995: 63).

Hipoplasia Linear do Esmalte Dentário

A hipoplasia se encontra relacionada ao desenvolvimento da dentição, onde para ser formada é necessário que ocorra uma interrupção na secreção da matriz durante a maturação do esmalte dentário que, nessa fase, possui $65 \%$ de composto mineral (hidroxiapatita) e $35 \%$ de orgânico (amelogenina e não amelogenina). Podendo ser originada por uma multiplicidade de fatores, geralmente tem sua causa mais recorrente ligada à distúrbios nutricionais ou algum fator de saúde, como febres relacionadas a alguma patologia infecciosa ou diabetes durante o período de desenvolvimento dentário. Sendo o registro mais expressivo encontrado nos dentes incisivos e caninos, por contar com um desenvolvimento bastante prolongado de 4-5 meses à 6-7 anos.

Hiperostose Porótica

$\mathrm{Na}$ análise da paleodieta de populações passadas, a Hiperostose Porótica é utilizada como um indicador não específico de estresse nutricional dentro dos estudos de Bioarqueologia. 
Caracterizada como uma expansão da díploe e o afinamento da tabela externa do osso, que é o resultado do aumento da produção de hemoglobina em resposta à anemia, causando uma hipertrofia da medula, resultando nas lesões de aparência porosa. Pode ser desencadeada por vários tipos de anemias, "Quando o padrão da hiperostose porótica sugere o envolvimento da dieta (lesões restritas para orbitas frontais e parietais) uma análise dos fatores ecológicos é essencial para a compreensão da causa primária" (Pince, et al, 1985: 438). A anemia pode estar associada a algum tipo de infecção, que alteraria o desenvolvimento ósseo, uma vez que as toxinas produzidas pelo patógeno irão ocasionar a morte de algumas células ósseas e elevar o periósteo ósseo. Resultando, deste modo, em uma aparência áspera e em um formato irregular para esse novo osso em formação (Prince, et al, 1985).

\section{Anemia}

Diferentes etiologias são responsáveis pela formação do quadro anêmico, sendo o da deficiência de Ferro (elemento responsável pela produção de hemoglobinas), sua causa principal. É definida como a redução da concentração de hemoglobinas na corrente sanguínea.

Ferro é encontrado em altas quantidades em carne vermelha, legumes e pescados, por exemplo. E é absorvido via intestinos. O ferro oriundo de plantas é de difícil absorção e componentes chamados fitatos nos cereais plantados como milho inibe a absorção do ferro (assim como a vitamina C auxilia na absorção) (Roberts; Manchester, 1995: 541).

Existem duas categorias de anemia: a genética (thalassemia e a sicklemia) e a adquirida (anemia megaloblástica), causada pela perda de sangue e deficiências nutricionais. Os elementos necessários para a manutenção da homeostase incluem aminoácidos essências, ferro, ácido fólico e vitaminas A, B12 e B6. Ambas as formas deixam marcas nos ossos, sendo as áreas do crânio as mais afetadas. Usualmente a anemia tem sua origem na carência alimentar, porém doenças infecciosas (como o escorbuto), também podem resultar no processo anêmico. Anemia e infecção possuem diferentes etiologias. "As transições de caçador-coletor para economias baseadas em agricultura revelam que os cereais utilizados para uma adequada variação alimentar levaram a uma deficiência de ferro no passado" (Roberts; Manchester, 1995: 541).

\section{Carência de Vitaminas C e D}

As vitaminas são fundamentais para o correto funcionamento do organismo. Uma deficiência em vitaminas, em especial na vitamina C (Ácido ascórbico), pode ocasionar várias mudanças 
esqueletais específicas, perceptíveis em populações passadas. A vitamina C é obtida em alimentos frescos e vegetais crus, sendo sua deficiência comum nos períodos de transição de modos econômicos de caçador-coletor para sociedades agricultoras, onde houve um aumento na ingestão de alimentos cozidos, gerando um crescimento nos índices de patologias orais, tais como cáries e abcessos. "Ambos comuns em acampamentos e comunidades assentadas, sendo o escorbuto, uma manifestação clínica da deficiência em vitamina C, isso é conhecido apesar de raros remanescentes osteoarqueológios" (Roberts; Manchester, 1995: 546). A vitamina C é fundamental no combate a infecções, na imunidade e na formação dos tecidos ósseos, em especial no colágeno e na absorção de ferro. Sua carência se encontra relacionada ao desenvolvimento do escorbuto em populações pretéritas. "Evidências esqueléticas do escorbuto, consiste na formação de um osso, potencialmente em lugar do esqueleto" Roberts; Manchester, 1995: 540). Sendo importante frisar que o conhecimento acerca da etiologia, vem fornecer dados sobre uma má nutrição e doenças infecciosas de populações passadas (Walker, et al., 2009).

A vitamina $D$ possibilita o organismo a absorver por meio da ingestão de alimentos o fósforo $e$ o cálcio, que são essenciais para a formação dos ossos, assim como para o funcionamento do sistema nervoso e cardiovascular. As fontes primárias de vitamina D são a luz solar e a alimentação. A sua deficiência pode gerar lesões na dentina e no esmalte dentário.

\section{Linhas de Harris}

Outro fator que pode ser associado ao estudo das paleopatologias, para a análise de paleodieta, é a ocorrência das Linhas de Harris, quando seus resultados estão associados a outros indicadores de estresse nutricional. As Linhas de Harris, também conhecidas como linhas de crescimento, ficam evidenciadas por intermédio do exame de Raios-X. Surgem com a absorção das arestas de cartilagem pelos osteoblastos, formando a cobertura do osso, ou seja, quando o crescimento da cartilagem é interrompido na placa epifisária e continua no final da diáfise adjacente, começando a crescer novamente. Esse crescimento ocorre tão lentamente no início, de modo que a deposição óssea nas diáfises permanece superando o crescimento longitudinal por um tempo, ocasionando um espessamento da zona de alta densidade óssea.

As Linhas de Harris indicam intervalos de estresse orgânico que ocasiona uma breve parada no crescimento e conduz a retomada logo após findado o fator de estresse. Normalmente, algumas dessas linhas tendem a ser absorvidas durante o desenvolvimento adulto do indivíduo, visto a 
remodelação contínua dos tecidos ósseos. Um fator associado as Linhas de Harris é a deficiência em vitamina D. De acordo com os experimentos de Hess \& Weistock em 1926, o tratamento de desordens nutricionais mediante a administração de fósforo (que é responsável pela formação das linhas transversas) em associação com o óleo de fígado de bacalhau (rico em vitamina D), ocasionou a cura da patologia.

Em 1978, Clarke desenvolveu um método para determinar a idade de início das Linhas de Harris de acordo com o padrão de crescimento de ossos longos conhecidos. A partir do desenvolvimento da tíbia, Clarke observou por meio de experimentos em adultos, que as linhas se iniciam por volta dos dois anos (período de desmame) e continuam até os treze anos, idade conhecida como o estirão da adolescência (Prince, et al.,1985).

\section{Cárie Dentária}

A cárie dentária é caracterizada pela destruição dos tecidos dentários calcificados (esmalte, dentina e cimento). Isso ocorre devido a ação de bactérias, por intermédio de ácidos, normalmente o ácido lático, resultado do processo de fermentação de carboidratos e açúcares, ocasionando a baixa do pH e a desmineralização dos dentes. "Ela é entendida como uma doença infecciosa complexamente modulada pela dieta e pelas condições ecológicas do ambiente oral" (Wesolowski et al., 2007: 143). O amido encontrado na alimentação torna-se outro fator cariogênico, sua digestão se inicia na boca, com a quebra de suas moléculas pela enzima ptialina. "Todos os tipos de açúcares da alimentação ocasionam uma rápida depressão do pH, podendo ser a glicose, maltosa, frutose, lactose etc. De longe, o efeito mais danoso é o da sacarose, que é matéria prima na produção de edulcorantes de alimentos" (Hillson, 1996: 278).

$\mathrm{O} \mathrm{pH}$ bucal tem um decréscimo, pelo consumo de amido não igualado ao açúcar, quando consumido, porém, com uma durabilidade maior, o que proporciona uma maior observação do amido cariogênico. "Se o alimento contiver amido e açúcar, terá um alto índice cariogênico" (Hillson, 1996: 278). Os tubérculos e os cereais são grandes fontes de amido encontradas na natureza. A inserção deles na alimentação de grupos passados pode ter ocasionado um efeito patológico na saúde oral dessas populações. Grupos indígenas em várias partes do mundo tiveram uma boa saúde bucal, com baixas taxas de cáries. Cenário esse apenas modificado pela adoção do cultivo de grãos e tubérculos, marcando também uma transição entre o Mesolítico e - Neolítico. O refinamento do modo de preparo dos açúcares e cereais aumentou a cariogenicidade dos mesmos, ocasionando através da coç̧ão aquosa a perda do fitato, um 
fosfato orgânico, solúvel com efeito anti cárie. "A dieta está relacionada ao processo saúdedoença, em muitos de seus aspectos e, em particular, a condições fisiopatológicas que afetam os dentes e a boca" (Wesolowski et al., 2007: 139).

\section{Abrasão Dentária}

Dentro dos desgastes acometidos aos dentes, há o atrito dentário, que pelo contato, ocasiona um desgaste entre a superfície oclusal e os pontos de contato. Existe também a abrasão dentária que, ao contrário do desgaste de superfície oclusal, não produz facetas claras uma vez que o mesmo ocorre mediante o contato com partículas abrasivas carregadas principalmente pela comida, por meio da língua e bochechas. A abrasão tende a ser pronunciada entre os humanos modernos pelo uso recorrente de escovação e da utilização de cremes dentais que produzem uma superfície brilhante (polida) e macia.

Nas populações pré-históricas pode-se observar que o padrão dentário se encontra diretamente relacionado a alimentação e ao processamento desse alimento que, por vezes, carregava consigo partículas de sedimento com alto teor abrasivo. Pode-se notar que a abrasão tende a ser mais pronunciada nessas populações no 1 o molar e tende a evoluir para o segundo e terceiro de forma progressiva. Isso se dá pela associação ao período de erupção dos dentes, ocasionando diferentes tempos de exposição às substâncias abrasivas, onde o primeiro tende a erupcionar aos 6 anos, o segundo por volta dos 12 anos e o terceiro somente após os 18 anos.

\section{Materiais}

Os trabalhos arqueológicos realizados nos sítios Justino e São José II (Figura 2), estão relacionados ao projeto de arqueologia de salvamento, (Figuras 3 e 4) efetuado durante a construção da UHE-XINGÓ, nas décadas de 1980 e 1990 (Fagundes, 2010). O local de inundação do lago da Companhia Hidroelétrica do São Francisco - CHESF, fica onde atualmente encontrase submerso o sítio Justino, localizado na Fazenda Cabeça de Nego, município de Canindé de São Francisco - SE, nas coordenadas: N 8.938.881/ E 627.561, com uma área de aproximadamente $1.500 \mathrm{~m}^{2}$ e cerca de $37 \mathrm{~m}$ de altitude em relação ao nível do mar. 


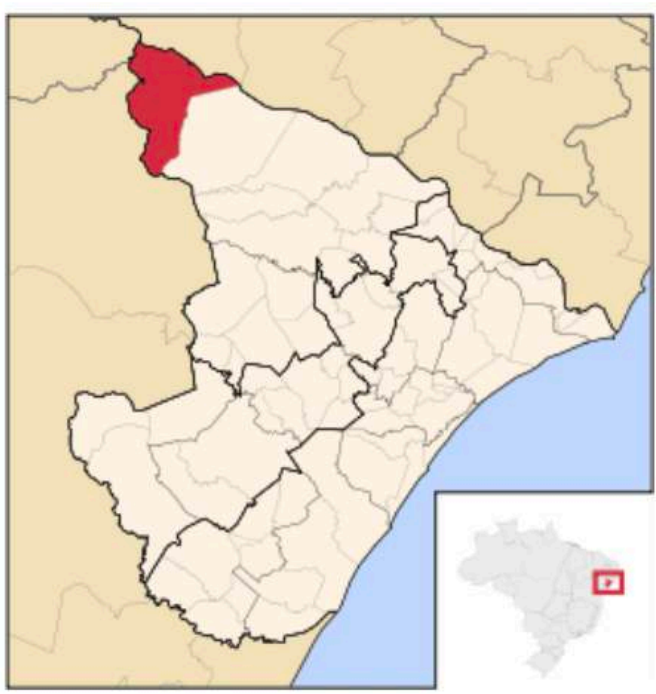

Figura 2: Município de Canindé de São Francisco (SE). Fonte: pt.wikipedia.org

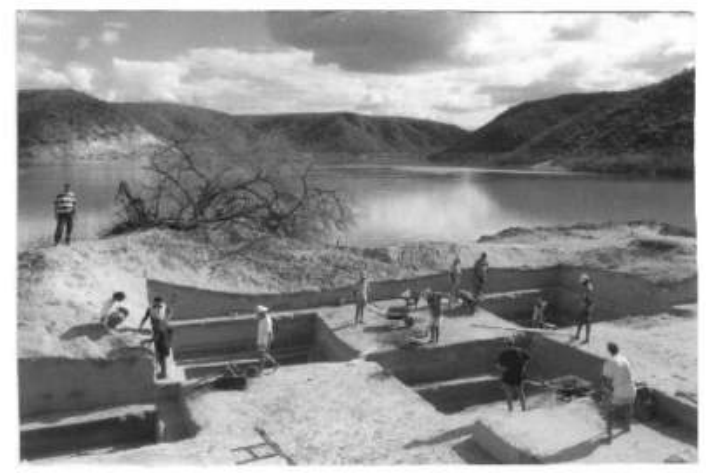

Figura 3: Escavações do sítio Justino. Fonte: Acervo MAX/UFS., 2017

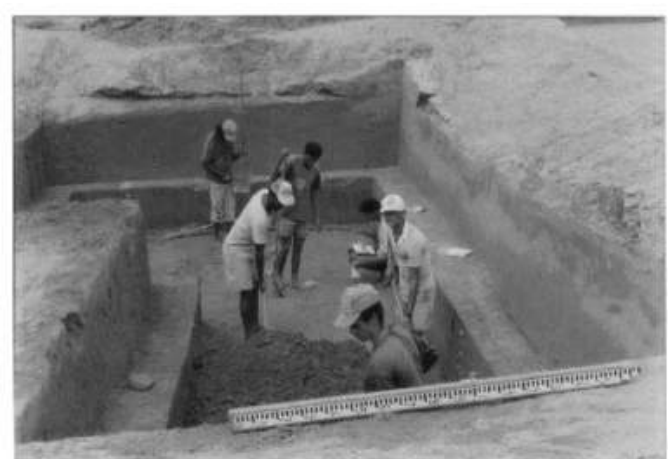

Figura 4: Escavações do sítio Justino. Fonte: Acervo MAX/UFS, 2017

Possui um total de 4 pisos de ocupações distintos, com datações entre 1280 e 8950 A.P. (Fagundes, 2004 e 2010; Vergne, 2002). De acordo com Fagundes, o local está associado as deposições sedimentares deltaicas, oriundas do riacho Curituba e de deposições advindas das cheias do rio São Francisco, sendo formadas distintas camadas aluvionares de areia fina, grossa, seixos, argilas e siltes.

O sítio São José II encontra-se na curvatura do riacho Talhado, com datações entre 3500 a 4100 anos A.P. Segundo Vergne (2002 e 2004), o período de escavações ocorreu entre janeiro de 1991 e junho de 1994, fazendo-se uso da metodologia de escavação de áreas abertas, chegando ao nível da rocha-mãe. Esse local se sobressai em relação aos demais, por sua grande quantidade de enterramentos e sepultamentos, totalizando 177 indivíduos, com uma ampla variedade entre ossos, cremações, sepulturas primárias e secundárias (Simon et al., 1999; Carvalho, 2006; Carvalho, 2007; Santana; Carvalho, 2013; Silva, 2013). 
Durante esse trabalho foram selecionadas 23 amostras de sepultamentos oriundas do sítio Justino e São José II, tendo no sítio Justino uma predominância de população adulta. No sítio São José ocorreu o oposto, a maioria de sepultamentos eram infantis.

\section{Metodologia}

A parte metodológica foi dividida em duas etapas, sendo a primeira realizada através da pesquisa bibliográfica. Na segunda foram realizadas as análises em laboratório, do material arqueológico existente no acervo do Departamento de Arqueologia da Universidade Federal de Sergipe -UFS e do Museu de Arqueologia de Xingó -MAX. Como o material já se encontra exumado foram selecionados para análise amostras de dentes, maxilares e mandíbulas do sítio Justino e São José II. Elementos esses que contêm melhores informações e indicadores da paleodieta e paleonutrição desses indivíduos. Nesse estudo foi utilizada a metodologia de Buikstra, J. E. B.; Ubelaker, D. H., (1994), para patologias orais, sendo observada a presença de cáries, abcessos, desgaste e ausência dentária. Para a análise dos dentes incisivos, caninos e pré-molares, foi usado o sistema de Murphy (1956 b), apud Buikstra, J. E. B.; Ubelaker, D. H., (1994), adaptado por Smith (1984), apud Buikstra, J. E. B.; Ubelaker, D. H., (1994), (Figuras 5 e 6), onde o desgaste é registrado em uma escala de 8 níveis relacionados à exposição da dentina.

1. Dente perdido, ou que não pode ser registrado.

2. Sem desgaste, com pequenas facetas polidas (sem exposição da dentina).

3. Debastamento das cúspides, com pontos de exposição da dentina.

4. Remoção completada cúspide, com exposição da dentina.

5. Grandes e variadas exposições da dentina, sem a ocorrência de manchas.

6. Duas manchas de dentina unidas.

7. Três ou quatro machas de dentina unidas, com a ocorrência de uma ilha de esmalte.

8. Exposição da dentina em toda a superfície oclusal, mantendo a borda do esmalte.

9. Perda grave da coroa, borda do esmalte incompleta, superfície da coroa com formato semelhante a raiz. 


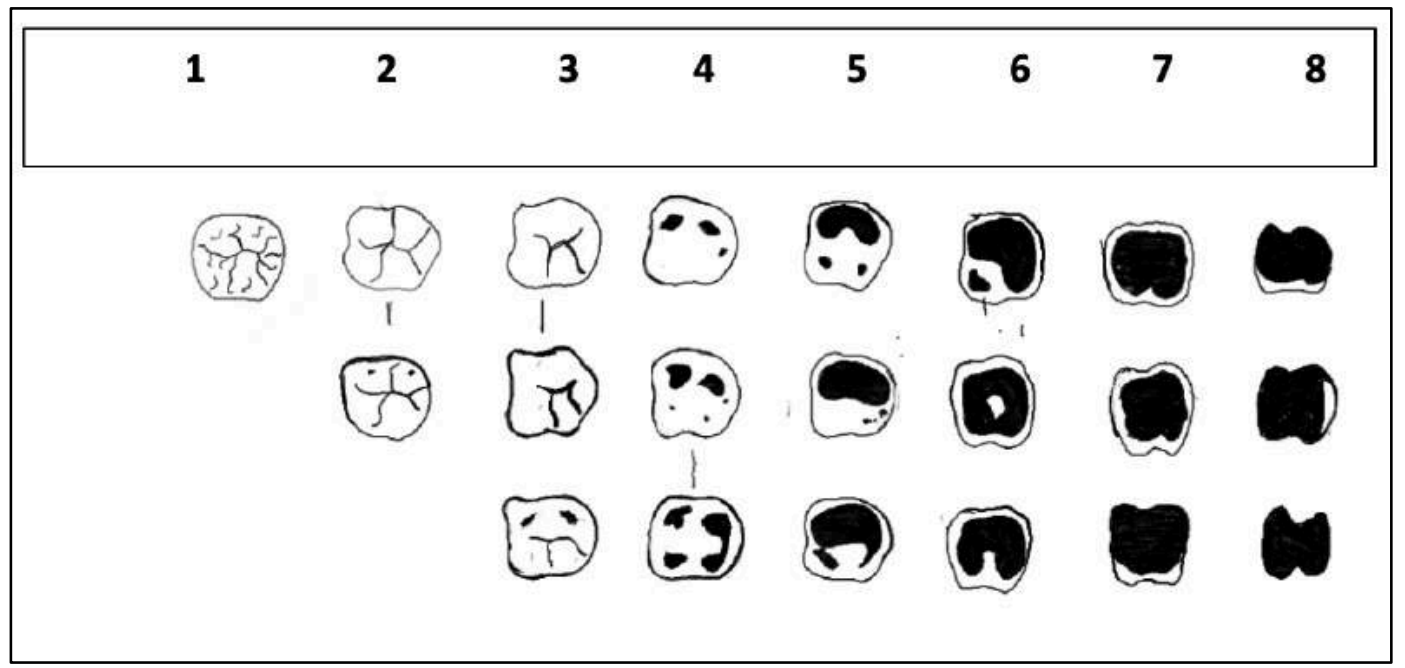

Figura 5: Diagrama dos níveis de abrasão das coroas dentárias. Adaptado de Smith (1984), apud Buikstra, J. E. B.; Ubelaker, D. H., (1994).

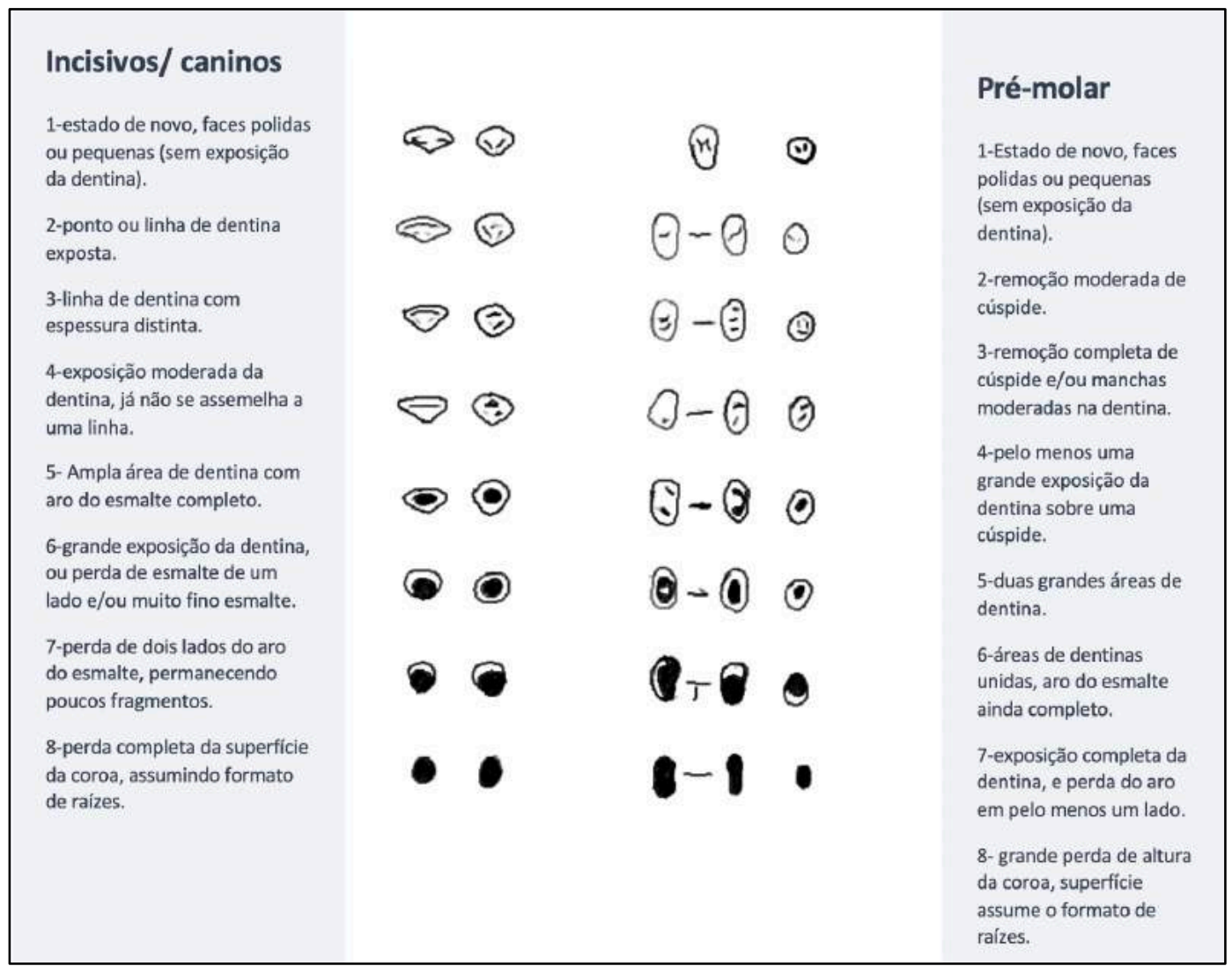

Figura 6: Níveis de Desgaste e Exposição da Dentina. Adaptado de Buikstra, J. E.B.; Ubelaker, D.H., (1994).

Sendo analisados vários tipos de paleopatologias orais relacionadas aos hábitos alimentares, dentro desse panorama foi efetuada a identificação, medição e registro de desgastes, cáries e outros elementos identificados. Para uma análise mais contundente dos dados verificados, foram criados gráficos percentuais, onde constam a presença/ausência de dentes das amostras 
de cada sítio por sepultamento, proporção de desgaste apresentado em cada dente e a presença/ausência de cárie. Durante a coleta de dados não foi identificada a presença de infecção cariosa, sendo encontrada o nível 7, de análise de cáries descrita em Buikstra, J. E.B.; Ubelaker, D.H., (1994), relativo a exposição de polpa não cariosa, que se encontrada associada há outros dentes com severa abrasão ou infecção cariogênica, mesmo que não sejam categorizadas como cáries, são registradas como a categoria 7, de acordo com a metodologia adotada.

Segundo Buikstra, Ubelaker, (1994), o sistema apresentado por Murphy (1956b), apud Buikstra, J. E. B.; Ubelaker, D. H., (1994) e adaptado por Smith (1984), apud Buikstra, J. E. B.; Ubelaker, D. H., (1994), se mostra pouco expressivo em casos de índices de desgaste relativamente baixos, sendo assim é indicada a adoção do sistema utilizado por Scott (1979), apud Buikstra, J. E. B.; Ubelaker, D. H., (1994), para molares. No sistema de Scott (1979), apud Buikstra, J. E. B.; Ubelaker, D. H., (1994), cada superfície molar oclusal é dividida em quadrantes e da quantidade do esmalte observável é pontuado em uma escala entre 1 e 10. A pontuação final gravada em cada dente é a soma das contagens para os quatro quadrantes, assim produzindo uma gama possível de 4-40.

Se qualquer quadrante não é observável, então o espaço na forma de gravação daquele dente deve ser deixado em branco. O registro ocorreu em tabelas adaptadas dos autores, referenciando os dentes de acordo com a Féderation Dentaire Internationale (FDI), notação dentária internacional, também conhecida como ISO-3950. A mesma segue e referência a visão do dentista, apresentados na Figura 7. 


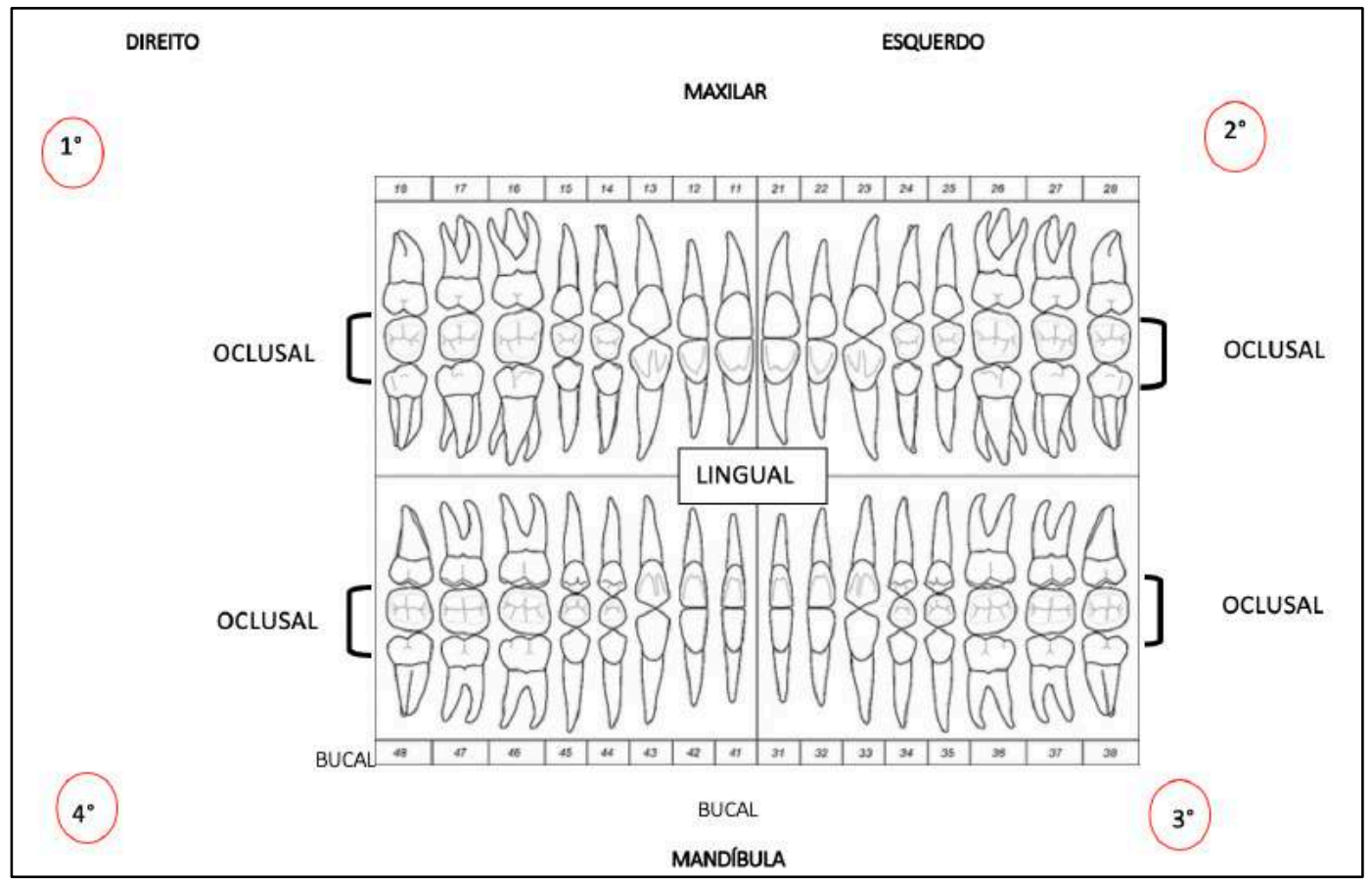

Figura 7: Odontograma Modificado de: Buikstra, J. E. B.; Ubelaker, D. H., (1994).

Para a análise das cáries foi utilizada Buikstra, J. E. B.; Ubelaker, D. H., (1994), com a modificação do sistema de Moore e Corbett (1971), apud Buikstra, J. E. B.; Ubelaker, D. H., (1994), apresentados na Figura 8. 0 mesmo emprega uma escala de 7 níveis, observadas na Figura 9.

\section{Resultados}

Foram realizadas análises em amostras de mandíbulas, maxilares e dentes dos sítios do Justino e São José II. Adotando a metodologia descrita por Buikstra, J. E.B.; Ubelaker, D.H., (1994). 


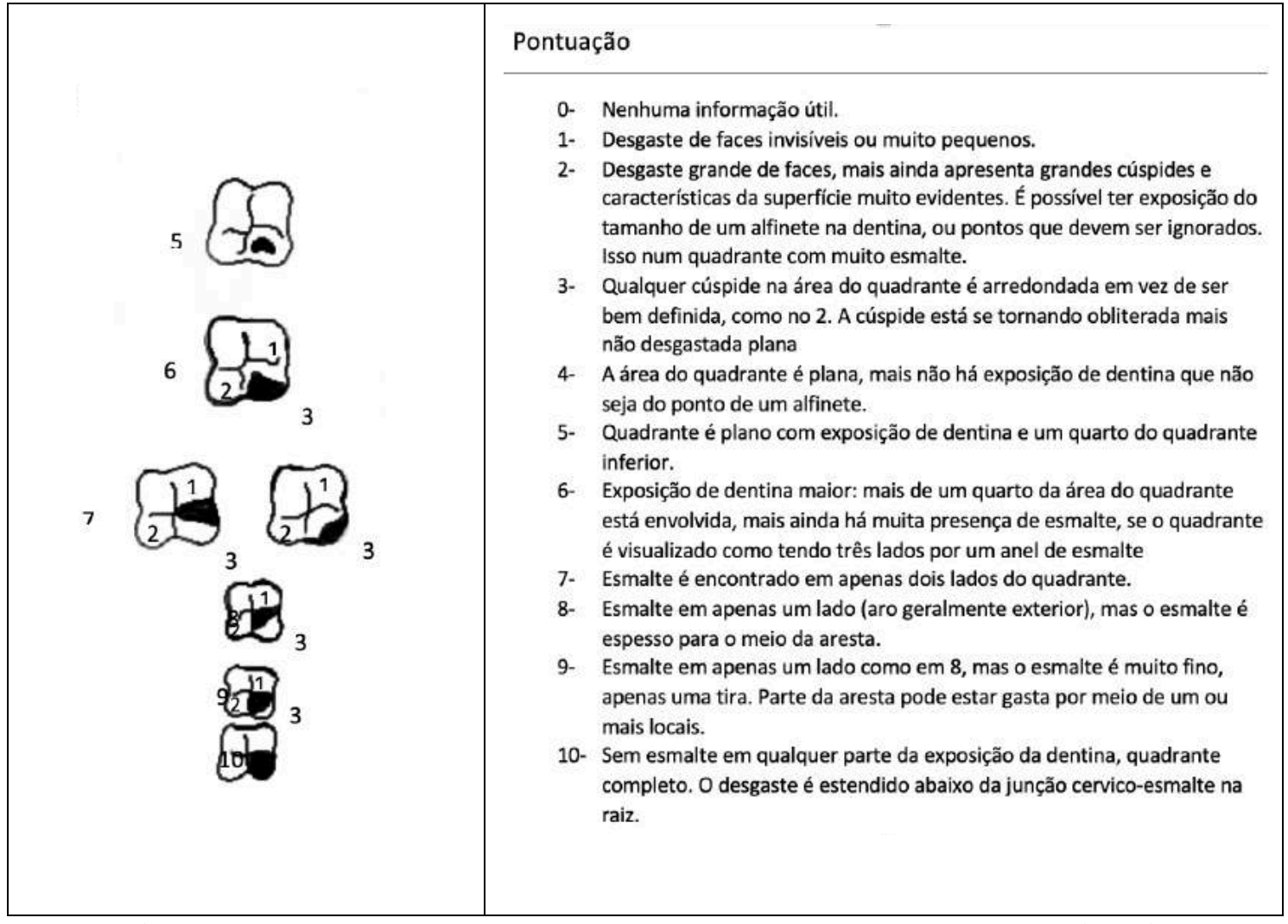

Figura 8: Níveis de desgaste para molares. Adaptado de Buikstra, J. E.B.; Ubelaker, D.H., (1994).
Pontuação / Descrição
1. Nenhuma lesão presente.
2. Superfície Oclusal: todos os sulcos, cúspides, poços, exposição de dentina, e os sulcos vestibulares e lingual dos molares
3. Superfície Interproximal: inclui as regiões mesial e distal cervical
4. Superfície lisa: superfície vestibular e lingual que não sulcos
5. Cáries cervicais: origina em qualquer esmalte cemento junção (cej), exceto nas regiões interproximais
6. Cáries de rais: próximas a CEJ
7. Cáries largas: cavidades que destruíram tanto do dente que eles não podem ser atribuídos a uma superfície de origem
8. $\quad$ Exposição de Polpa não cariosa

Figura 9: Escala de níveis de cáries, adaptado de Buikstra, J. E.B.; Ubelaker, D.H., (1994).

No sítio Justino foram analisados no total 20 sepultamentos: $21 ; 25 ; 45 ; 50 ; 53 ; 54 ; 75 ; 77 ; 79$; 81; 92; 95; 96; 97; 98; 109; 118; 120; 134; 140. Predominou o tipo de enterramento primário, exceto no caso dos sepultamentos 96, 97 e 98, todos masculinos. No sepultamento 95 foi identificada a presença de um dente supranumerário heterotópico no palato. Segundo Castro 
(2016), foi observada a provável presença de tártaro no sepultamento 25 e a presença de cálculo no sepultamento 96 . O dente $38 \mathrm{M}^{3}$ não foi notificado. $\mathrm{O}$ dente $28 \mathrm{M}^{3}$ aparece de forma dominante no sítio, no entanto não apresentou patologias. Esses dados podem ser observados no gráfico 1. O maior índice de desgaste foi identificado nos molares, tanto superiores, quanto inferiores; já o maior percentual de exposição de polpa $<40 \%$, nos dentes $25 \mathrm{P}^{2}, 44 \mathrm{P}^{1}$ e $43 \mathrm{C}$.

Gráfico 1: Sítio Justino. Fonte: Iris Machado, 2012.

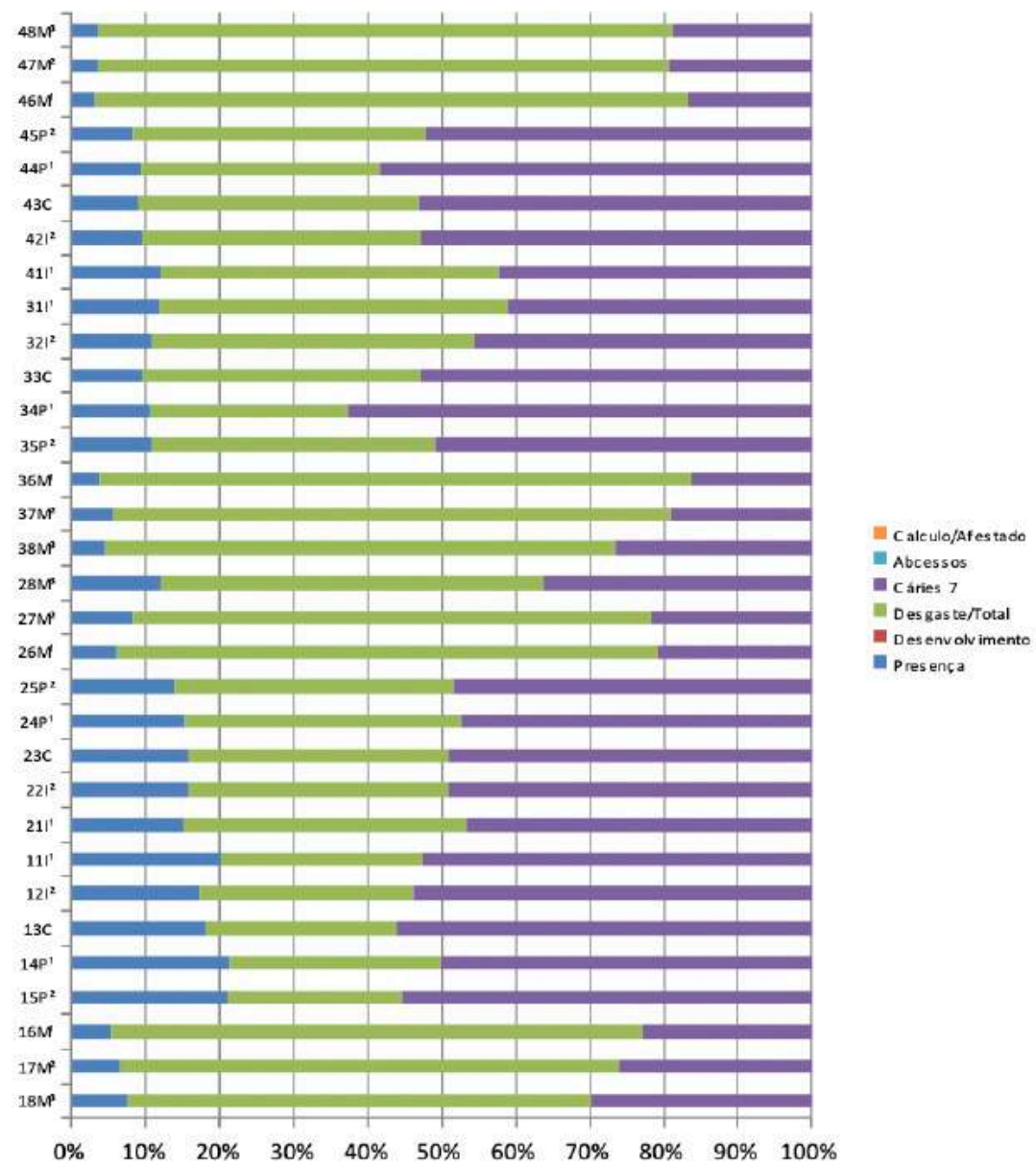

Foram analisados 17 sepultamentos, sendo eles: $21 ; 25 ; 45 ; 50 ; 53 ; 54 ; 75 ; 77 ; 79 ; 81 ; 92 ; 95$; $96 ; 97 ; 98 ; 109 ; 118 ; 120 ; 134 ; 140$. Tendo como maior proporção de desgaste os dentes $48 \mathrm{M}^{3}$; $47 \mathrm{M}^{2} ; 46 \mathrm{M}^{1} ; 36 \mathrm{M}^{1} ; 37 \mathrm{M}^{2}>80 \%$ e sua presença inferior a $<10 \%$. Nos dentes $11 \mathrm{I}^{2} ; 14 \mathrm{P}^{1} ; 15 \mathrm{P}^{2}$, o desgaste alcançou $>\mathbf{2 0 \%}$ e a exposição de polpa não cariosa (cárie 7) marcou $>50 \%$. Os dentes:

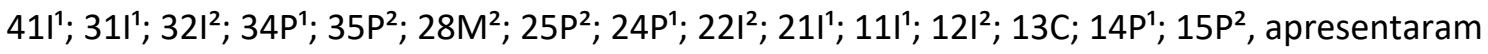
presença $>10 \%$. No sepultamento 134 (Figuras 10 e 11), foi constatado a presença de hipoplasia linear, porém não houve como realizar uma análise do desgaste pela má conservação, e do crânio encontrar-se articulado. 


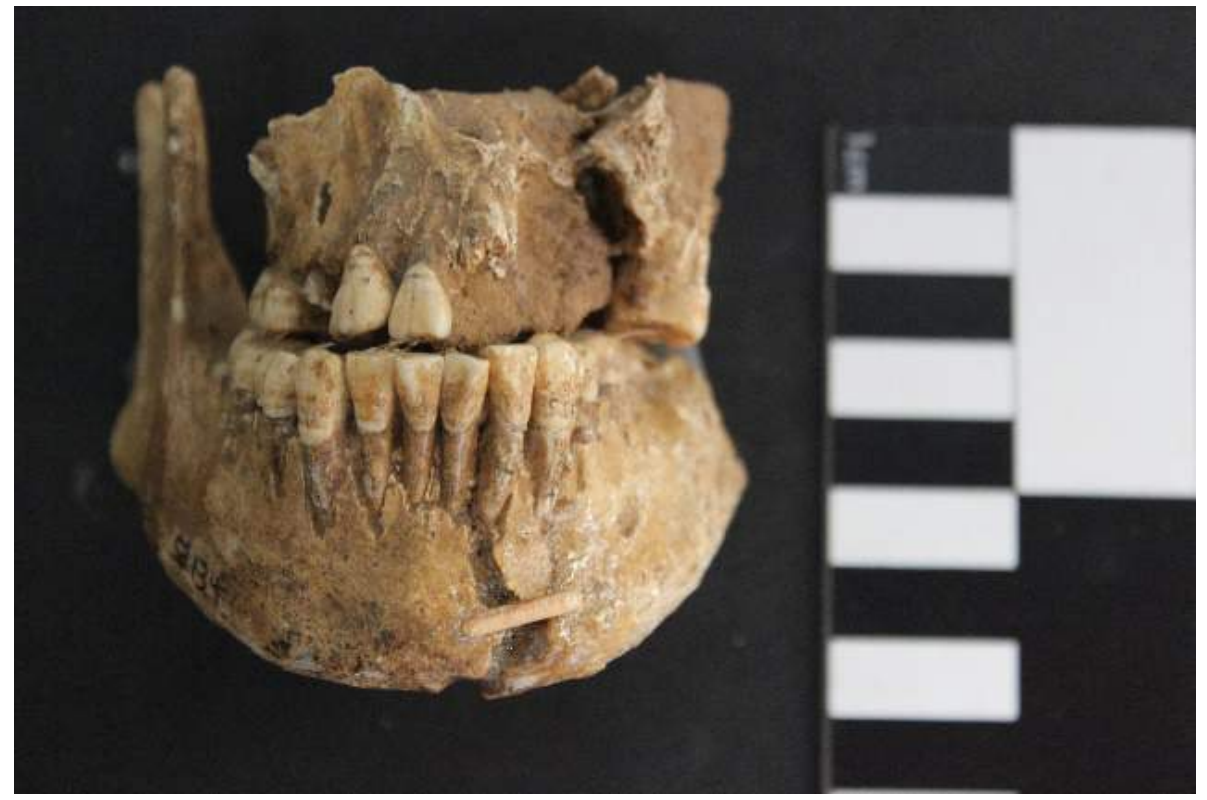

Figura 10: Sepultamento 134, vista frontal. Sítio Justino. Fonte: Acervo pessoal, 2017.

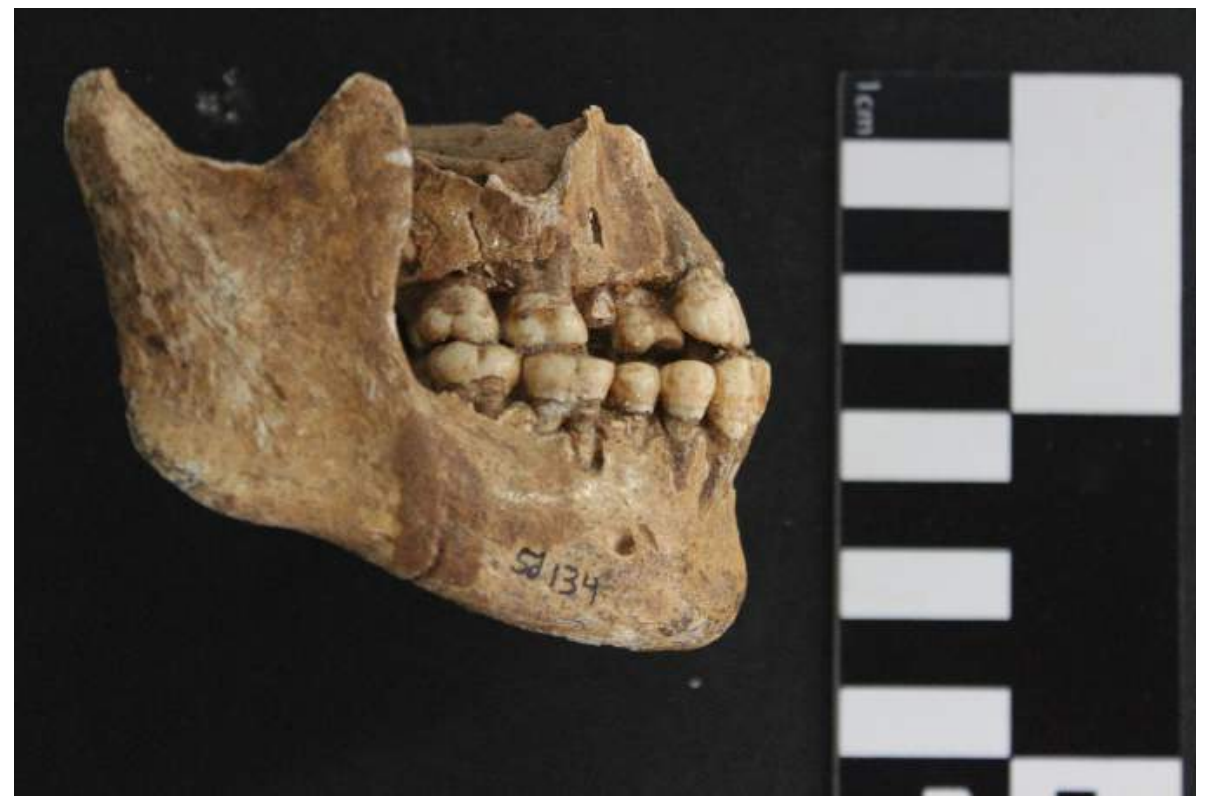

Figura 11: Sepultamento 134, vista lateral (as hipoplasias se encontram evidenciadas), sítio justino. Fonte: Acervo pessoal, 2017.

O sepultamento 118 do sítio Justino (Figuras 12, 13 e 14), caracteriza-se por um enterramento primário onde é visível a perda de dentes ante mortem. A abrasão forte dos dentes, que pode estar associada a sua alimentação e seu modo de vida em conjunto com sua idade, permite estimar sua idade na classe dos 50-59 anos, sendo um indivíduo do sexo masculino. 


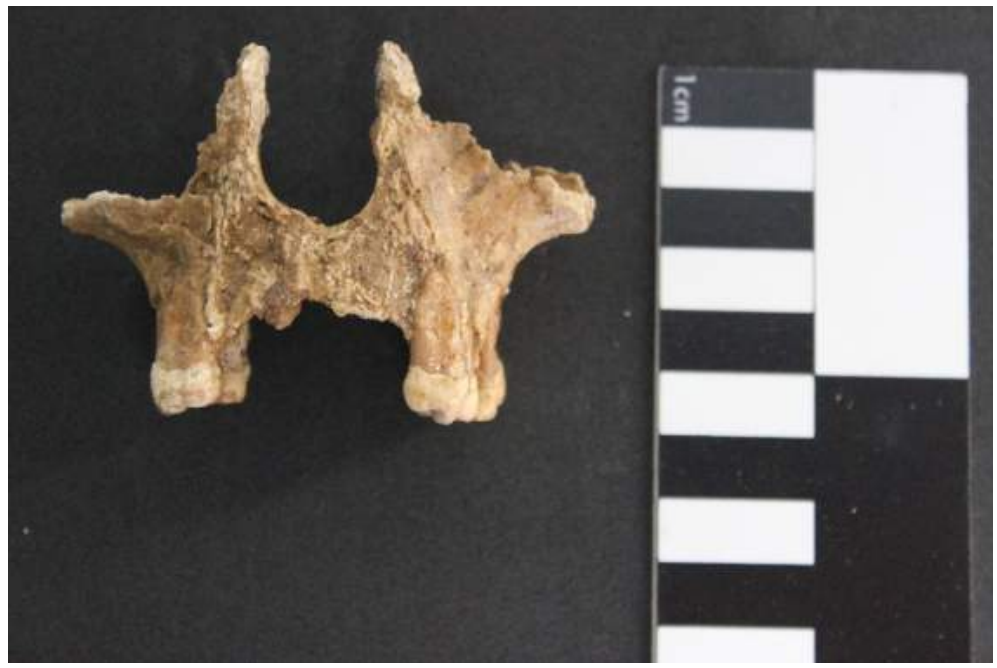

Figura 12: Sepultamento 118 (sítio Justino) maxilar, vista frontal. Fonte: acervo pessoal, 2017.

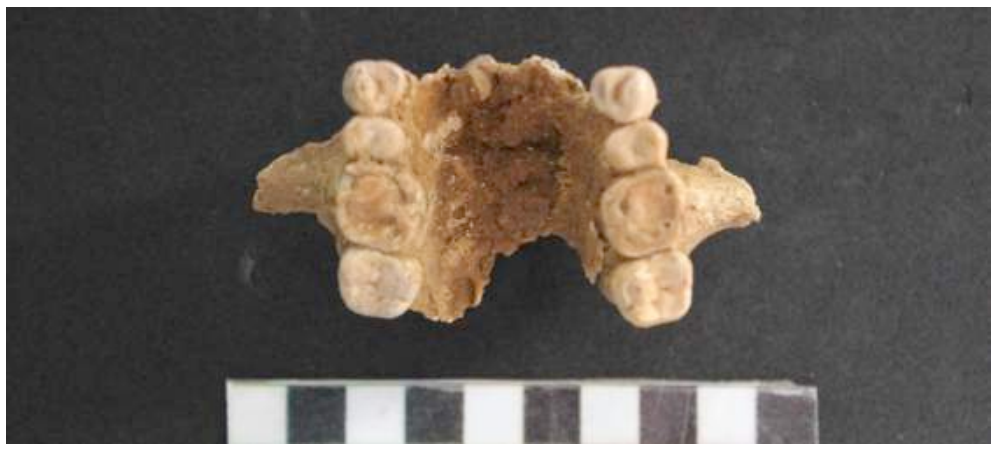

Figura 13: Sepultamento 118 (sítio Justino), maxilar vista oclusal. Fonte: Acervo pessoal, 2017.

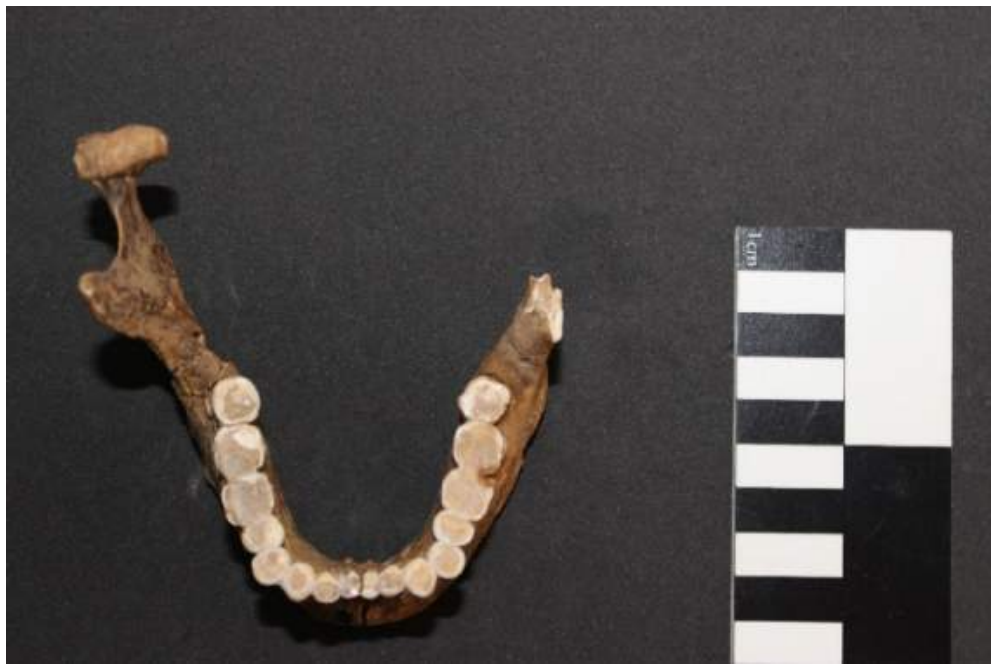

Figura 14: Sepultamento 118 (sítio Justino), mandíbula vista oclusal. Fonte: acervo pessoal, 2017.

No sítio São José II tem-se uma diferença dos sepultamentos dos observados no Justino (Figuras 15, 16 e 17). Nesse presentam-se dentições em sua maioria decíduas e em fase de transição, oscilando a presença de dentes entre 20-32, (decíduo/adulto). Não foi registrada a presença de 
patologias orais e de desenvolvimento em dente da arcada inferior. Na dentição superior foi registrada a presença plena dos dentes $14 \mathrm{P}^{1} ; 15 \mathrm{P}^{2} ; 16 \mathrm{M}^{1}$. Nos dentes $28 \mathrm{M}^{3} ; 27 \mathrm{M}^{2} ; 26 \mathrm{M}^{1}$, o índice de desgaste ficou $>70 \%$, nos demais concentrou-se entre $40-55 \%$, podendo ser observados no gráfico 2.

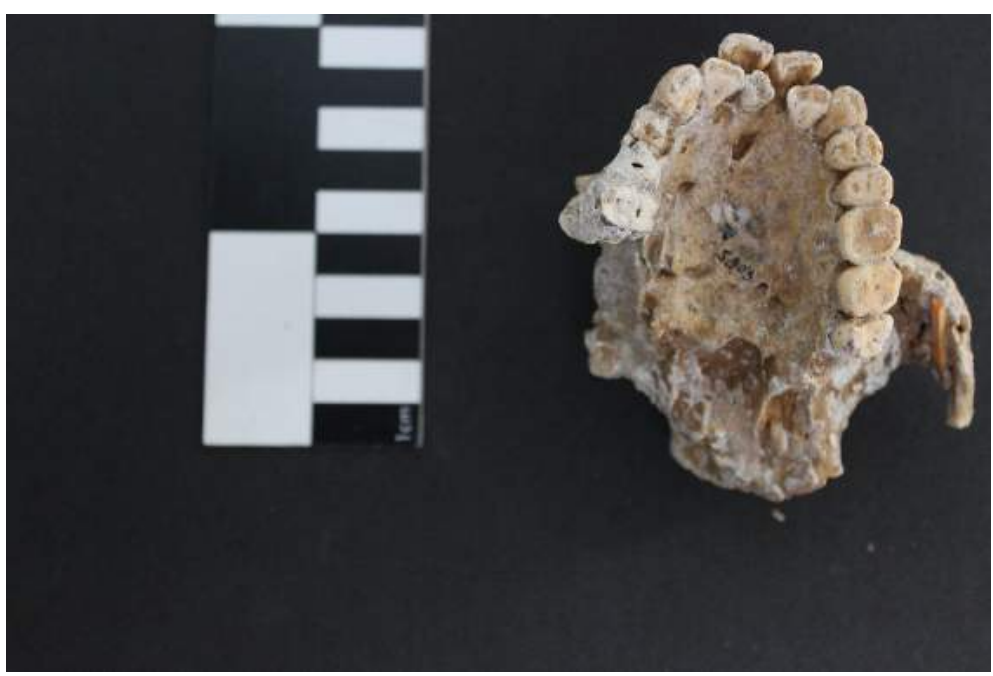

Figura 15: Sepultamento 03 (sítio São José II), Maxilar, vista oclusal, é possível observar a presença de um dente supranumerário. Fonte: Acervo pessoal, 2017.

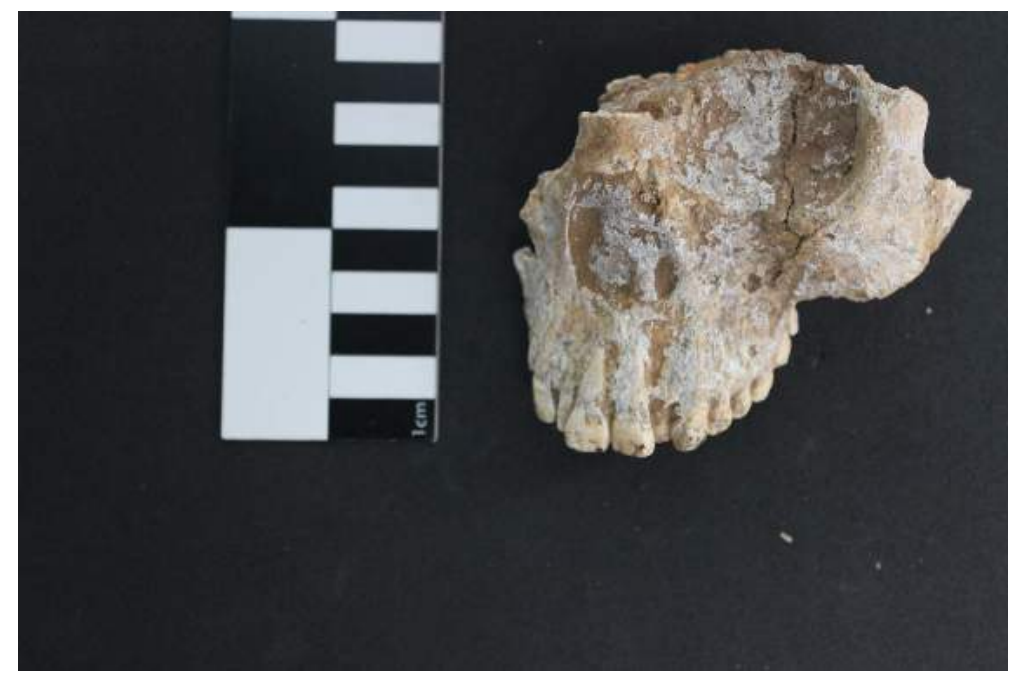

Figura 16: Sepultamento 03 (sítio São José II), maxilar, vista frontal. Fonte: Acervo pessoal, 2017. 


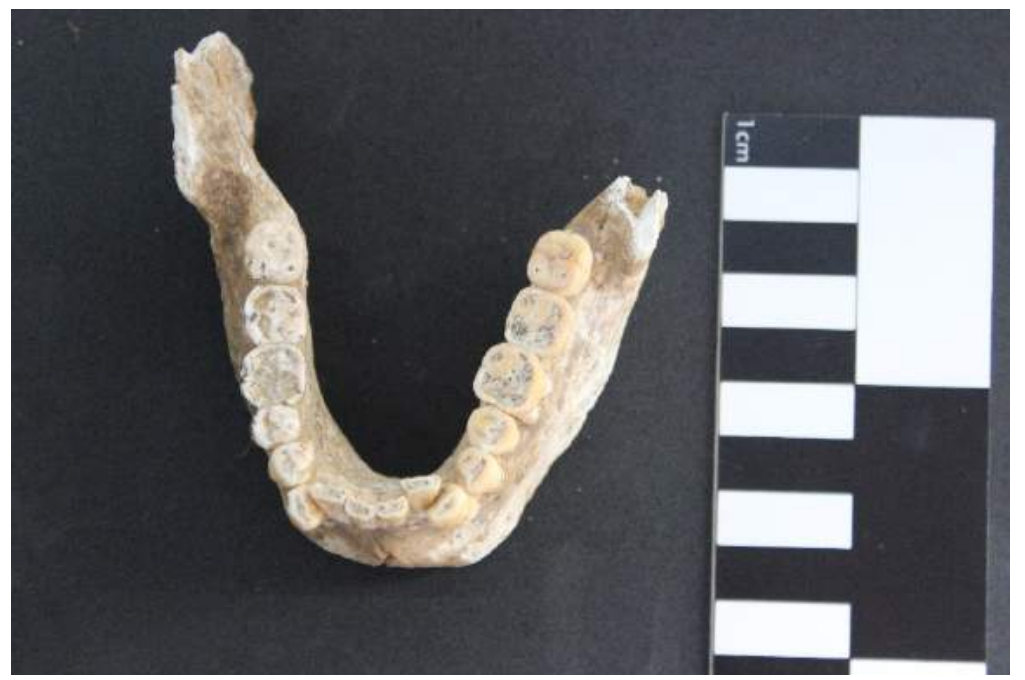

Figura 17: Sepultamento 03 (sítio São José II), mandíbula, vista oclusal. Fonte: Acervo pessoal, 2017.

Gráfico 2: Sítio São José II. Fonte: Iris Machado, 2012.

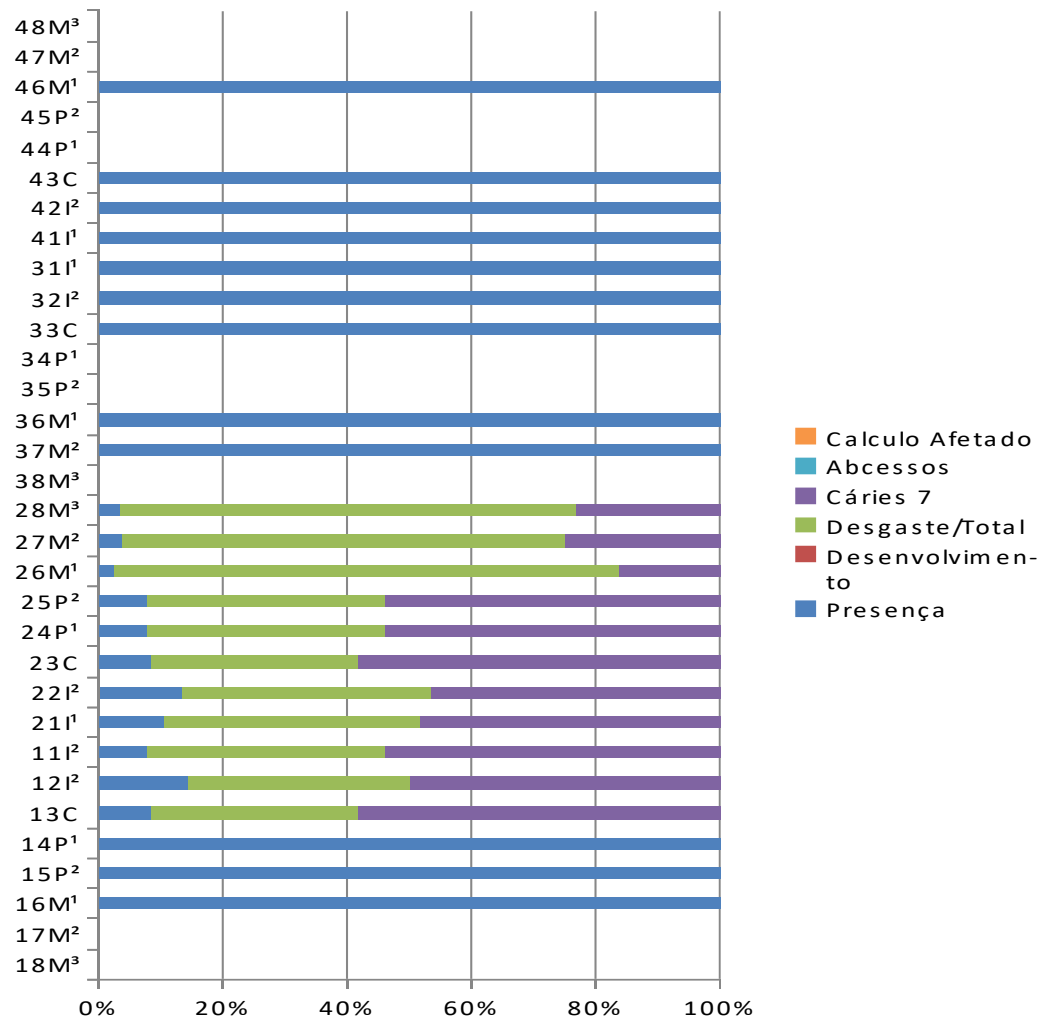




\section{Conclusões}

No total foram analisados 23 sepultamentos, sendo 17 do sítio Justino e 6 do São José II. No sítio Justino predomina a população adulta nos sepultamentos, diferente do observado no sítio São José II, onde a maioria de enterramentos infantis. Neste sítio verificou-se um estado de saúde oral bem preservado, havendo um pequeno quantitativo de dentes com a presença de abrasão dentária elevada, diferente do encontrado no Justino. No sítio Justino foi observada uma alta proporção de abrasão dentária e de exposição de polpa não cariosa. Não foram registradas patologias orais infeciosas significativas, no entanto, as taxas de abrasão elevadas na maioria dos sepultamentos analisados sugerem o uso predominante de alimentos duros e grosseiros, presentes em populações caçadoras-coletoras, devido a seu hábito alimentar e sua forma de preparo e processamento dos alimentos.

\section{Referências}

BUIKSTRA, J. E. B.; UBELAKER, D. H. 1994. Standars for data collection from human remains. Arkansas Archaeological Survey Research, n.44. pp.1-206.

BRICE, T.D.; MARGARET, J. S.; ARMELAGOS, G. J. 1985. Bone Chemistry and Past Behavior: an Overview, Journal of Human Evolution 14, pp. 419-447.

CARVALHO, O. A. 2006. Contribution a L'Archeologie Bresilienne: Etude paleoanthropologique de deux necrópoles de la region de Xingo, état, de Sergipe, nord-est du Brésil. 2006. 506 f. Thèse de Docteur. Faculté des Sciences de l'Université de Genève, Genève.

CARVALHO, O. A. 2007. Bioanthopologie des nécropoles de Justino et de São José II, Xingó, Brésil. Canindé do São Francisco: Museu de Arqueologia de Xingó.

FAGUNDES, M. Entendendo a Dinâmica Cultural em Xingó na Perspectiva Inter Sítios - Indústrias Líticas e os Lugares Persistentes no Baixo Vale do Rio São Francisco, Nordeste do Brasil. Arqueologia Iberoamericana, v.06, pp.03-23, 2010.

FAGUNDES, M. ; VERGNE, M. C. S. 2004. Atributos tecnológicos da indústria lítica do sítio Barragem (decapagens 01 a 06), Xingó, Alagoas. Canindé - Revista do Museu Arqueológico de Xingó, Aracaju, v. 04, pp. 09-54.

GLÓRIA, P.J. 2006. Estilo e qualidade de vida biológica em San pedro de Atacama: o que dizem os esqueletos subadultos. Tese de mestrado, UFP, 2017 páginas.

GOODMAN et al., 1997

HILLSON, S. 1996. Dental Anthropology. New York, Cambridge. 
KATZEMBERG, M.A.; HARRISON, R. G. 1997. What's in a Bone? Journal of Archaeological Research, v. 5, n. 3.

MENDONÇA DE SOUZA, S. M. F. 1999. Anemia e Adaptabilidade em um Grupo Costeiro Pré-Histórico: uma Hipótese Patocenótica. Pré-História da Terra Brasilis. 1 ed. Rio de Janeiro: Editora UFRJ, v., pp. 171-188. ROBERTS, C.; MANCHESTER, K. The archaeology of disease. Ithaca, New York, Cornell University Press. 1995.

SANTANA, E. A.; CARVALHO, O. A. 2013. Fraturas nos ossos: violência, acidente ou bioturbação?. Cadernos do LEPAARQ (UFPEL), v. 10, p. 131-157.

SIMON, C.; CARVALHO, O. A.; QUEIROZ. A. N.; CHAIX, L. 1999. Enterramentos na Necrópole do Justino Xingó. PAX/UFS.

SILVA, J. A. 2013. O corpo e os adereços: Sepultamentos humanos e as especificidades dos adornos funerários. Dissertação (Mestrado em Arqueologia). Universidade Federal de Sergipe, São Cristóvão. TRANCHO, G. B ; ROBLEDO, B. 1999. Paleodieta: estudio del alimentício em El Cerro de la Cabeza (Ávila). Universidad Complutense. Madrid.

VERGNE, M. C. S. 2002. Estruturas funerárias do sítio Justino: Distribuição no espaço e no tempo. Revista Canindé, Sergipe, $\mathrm{n} 2$.

VERGNE, M. S. C. 2004. Arqueologia do Baixo São Francisco: estruturas funerárias do sítio Justino - Região de Xingó, Canindé de São Francisco, Sergipe. 352 f. Tese (Doutorado em Arqueologia). Universidade de São Paulo, Faculdade de Filosofia, Letras e Ciências Humanas, Museu de Arqueologia e Etnologia, São Paulo.

WALKER, P. L., BATHURDT, R. R., RICHMAN, R., GJERDRUM, T. 2009. The causes of porotichyperostosis and cribra orbitalia: a reappraisal of the iron-deficiency-anemia hypothesis. 139:109-125.

WESOLOWSKI, V. ; Mendonça de Souza, S.F. ; Reinhard, K. ; Cecantinni, G. . Grânulos de amido e fitólitos em cálculos dentários humanos: contribuição ao estudo do modo de vida e subsistência de grupos sambaquianos do litoral sul do Brasil. Revista do Museu de Arqueologia e Etnologia, p. 191, 2007.

WHITE, T., FOLKENS, P. A. 2000. Human osteology. Second Edition. Academic Press. 